\title{
Somersall, Subrogation AND THE SUPREME COURT: How THE TOP COURT'S RULING IN SOMERSALL V. FRIEDMAN Undermines Insurance Law Theory and Practice
}

\section{BARBARA BILLINGSLEY}

\section{INTRODUCTION}

Subrogation - as I regularly and repeatedly tell my insurance law students - is a fundamental insurance law principle which goes "hand in hand" with the purpose of indemnity served by most insurance contracts.' Generally, insurance coverage enables an insured to receive compensation for his or her loss without having to sue the party responsible for causing the loss (the wrongdoer). In exchange for providing this upfront compensation, the insurer gains the equitable right to subrogate against the wrongdoer - that is, to step into the shoes of the insured and to sue the wrongdoer in order to recover some or all of the money paid out by the insurer to the insured. ${ }^{2}$ As part of the overall system of indemnity insurance, subrogation is therefore relied upon as the key to ensuring justice for all: the insured receives prompt compensation under the policy without the expense of suing the wrongdoer; the insured is prevented from simultaneously recovering from the insurance company and the wrongdoer and thereby double-recovering for the loss; the insurer gains the legal right to recoup its payout under the policy by suing the wrongdoer; and the wrongdoer remains subject to legal liability for causing the loss despite the fact that his or her victim had applicable insurance coverage. ${ }^{3}$ Further, as a practical matter, the ability to recoup from a wrongdoer money paid out under an insurance contract may be a mitigating factor which insurers take into account in setting insurance rates. ${ }^{4}$

Recently, in Somersall v. Friedman, ${ }^{5}$ the Supreme Court of Canada addressed the doctrine of subrogation and, in particular, the contractual obligations of an insured to preserve an insurer's right of subrogation. A 5-2 majority of the Court essentially concluded that, barring circumstances involving bad faith or malice, an insured has no enforceable obligation to protect an insurer's potential subrogated action. This ruling

Barbara Billingsley, Assistant Professor, Faculty of Law, University of Alberta. She practised insurance law from 1990 to 1996, and has taught it since 1995.

1 In a very general sense, all insurance policies are contracts of indemnity in that they compensate an insured for a particular loss. Under a true indemnity policy, however, the payment to the insured reflects the actual pecuniary loss suffered, up to the policy limits. In contrast, under a valued policy, such as life insurance, the insured is paid a predetermined amount upon the happening of the insured-against event, irrespective of the actual pecuniary loss suffered by the insured as a result of that event. The doctrine of subrogation goes hand in hand with a true indemnity policy but plays no role in a valued policy.

2 Of course, the insurer can only sue the wrongdoer where the insured would have had a legally enforceable right against the wrongdoer to recover the amount of loss caused. For further discussion see C. Brown, et al., Insurance Law in Canada, looseleaf (Scarborough: Thomson Canada, 2002) at 13.2-13.10.

3 For further discussion of the objectives of subrogation, see C. Brown, ibid. at 13.2-13.3.

4 As this commentary will indicate, whether or not insurers actually set premiums based on the notion that they will recoup some expenses through subrogation is a point of contention between lacobucci J. and Binnie J.

3 [2002] S.C.J. No. 60, online: QL (SCJ) [hereinafter Somersall (S.C.C.)]. 
significantly misconstrues, underestimates, and undermines subrogation as a fundamental principle of both insurance law theory and practice. My reasons for characterizing the Supreme Court's decision in this fashion are the subject of this comment.

\section{THE FACTS}

On 29 January 1989, Pearl and Gwendolyn Somersall were involved in a car accident allegedly caused by Jerry Friedman. On 28 January 1991, the Somersalls commenced a lawsuit against Friedman seeking compensation for loss and injuries arising from the accident. The claim exceeded the $\$ 200,000$ policy limits of Friedman's automobile liability insurance. On 13 December 1991, the Somersalls entered into a limits agreement with Friedman which provided, inter alia, that while continuing to pursue their liability claim against Friedman, the Somersalls would not claim damages against Friedman or his automobile liability insurer in excess of the amount of Friedman's policy limits.

The Somersalls entered into the limits agreement without first advising or consulting their own automobile insurer, the Scottish \& York Insurance Company. On 4 July 1994, the Somersalls added the insurer as a defendant in the action against Friedman, claiming payment from the insurer pursuant to an SEF 44 endorsement $^{7}$ for the amount their claim exceeded Friedman's insurance limits. The insurer cross-claimed against Friedman on the grounds that the SEF 44 entitled the insurer to subrogate against the tortfeasor for any damages paid under the SEF 44. Friedman argued that this crossclaim was barred by the terms of the limits agreement.

\section{THE Legal ISSUES ${ }^{8}$}

Prior to the trial of the Somersalls' claim against Friedman, a chambers application was brought to decide a preliminary point of law: namely, whether the limits agreement precluded the Somersalls from claiming against their insurer under the SEF 44. In addressing this question, the insurer advanced two arguments, which for convenience I will refer to respectively as the entitlement argument and the subrogation argument. In the entitlement argument, the insurer contended that, as a result of the limits agreement, the Somersalls no longer fell within the terms of the SEF 44 insuring agreement. According to the entitlement argument, because the Somersalls had agreed not to pursue Friedman for any damages over the limits of Friedman's liability insurance, the Somersalls' claim was not covered by the SEF 44, which obliged the

6 Summarized from Somersall v. Friedman, [1998] O.J. No. 2223 (Ont. Ct. Gen. Div.), online: QL (OJ) [hereinafter Somersall (Gen. Div.)]; Somersall v. Friedman, [2000] O.J. No. 401 (C.A.), online: QL (OJ) [hereinafter Somersall (C.A.)], and Somersall (S.C.C.), ibid.

Generally, an SEF 44 endorsement allows an insured to recover, from his or her own automobile insurer, compensation (up to the limits of the endorsement) for bodily injury or death caused by another motorist where the amount the insured would be legally entitled to recover from the wrongdoer exceeds the amount of the wrongdoer's applicable liability insurance. The relevant provisions of the SEF 44 endorsement at issue in this case are set out in Somersall (S.C.C.), ibid. at para. 7.

$8 \quad$ See supra note 6. 
insurer to pay any amount that the insured was "legally entitled to recover" from an underinsured tortfeasor motorist. In the alternative, in the subrogation argument, the insurer submitted that, if the effect of the limits agreement was to preclude the insurer from subrogating against Friedman for any monies paid under the SEF 44, then the Somersalls had breached the terms of the SEF 44 contract and were not entitled to payment. In other words, if the limits agreement relieved Friedman of any legal obligation to pay for the Somersalls' damages over the amount of Friedman's insurance coverage, then by entering into the limits agreement the Somersalls had prejudiced the insurer's ability to subrogate against Friedman. The Somersalls thereby breached their contractual duty to co-operate with the insurer and were therefore not entitled to payment under the SEF 44.

\title{
IV. The LOWER COURTS' Decisions
}

On 4 June 1998, Spiegel J. of the Ontario Court (General Division) accepted the entitlement argument and ruled that the limits agreement did bar the Somersalls' claim against the insurer. ${ }^{9}$ According to Spiegel J., in order to successfully claim under the SEF 44, an insured "must have an enforceable right of action to recover compensatory damages against the tortfeasor for an amount which is in excess of the tortfeasor's insurance limits." The only exception is in "cases where the insured's right to proceed against the tortfeasor is barred by virtue of a limitation period." Justice Spiegel then concluded that the limits agreement eliminated any claim the Somersalls might have had against Friedman for any amount in excess of Friedman's insurance limits, and the claimants were therefore barred from proceeding against the insurer. Having made this finding on the entitlement argument, Spiegel J. did not address the subrogation argument.

On 16 February 2000, in a judgment written by Charron J.A., the Ontario Court of Appeal unanimously overturned the ruling of the chambers justice. ${ }^{12}$ With respect to the entitlement argument, Charron J.A. accepted the Somersalls' submission that the phrase "legally entitled to recover damages" in the SEF 44 endorsement simply requires the claimant to "establish (1) that the tortfeasor is at fault and (2) the amount of damages caused by such fault."13 Since the Somersalls' action against Friedman would

\author{
Somersall (Gen. Div.), ibid. \\ Ibid. at para. 56. \\ Ibid. \\ Somersall (C.A.), supra note 6.
}

Ibid. at para. 11. Justice Charron's finding in this regard was based on previous rulings by the Ontario Court of Appeal in Johnson v. Wunderlich (1986), 57 O.R. (2d) 600 and Chambo v. Musseau (1993), 15 O.R. (3d) 305, where the court had ruled that the words "legally entitled to recover damages" in an SEF 44 endorsement required the claimant to establish only the fault of the underinsured tortfeasor and the resultant damages suffered by the claimant. In the words of Charron J.A., ibid., at para. 18 ,

The recognition that an insured has a direct right of action against his insurer which does not require a prior judicial determination of liability against the tortfeasor is crucial in the determination of the question on this appeal. It means that the appellants can bring their action against $S \& Y$ without exhausting their remedies against Friedman. The necessary elements of the action are (1) an eligible claimant (2) who is legally entitled to recover compensatory damages from a motorist (3) who is inadequately insured. For the purposes 
determine these issues, the Somersalls were entitled to claim against the insurer. Justice Charron gave short shrift to the subrogation argument, essentially holding that any interference with the insurer's subrogation right caused by the limits agreement was irrelevant as long as the two criteria stated above had been met. ${ }^{14}$

\section{The Supreme Court of Canada Decision ${ }^{15}$}

In a judgment written by lacobucci J., a five-member majority of the Supreme Court ${ }^{16}$ rejected both the entitlement and the subrogation arguments and held that the limits agreement did not bar the Somersalls from claiming against the insurer under the SEF 44. In a harsh dissenting judgment written on behalf of himself and Major J., Binnie J. essentially accepted both arguments. Although the entitlement argument also raises significant insurance law issues, for the purposes of this comment I will focus exclusively on the Supreme Court's comments regarding the subrogation argument. ${ }^{17}$

of this appeal, we can assume that the appellants are eligible claimants and that Friedman is inadequately insured. As determined in Johnson v. Wunderlich, in order to prove that they are legally entitled to recover compensatory damages against Friedman, the appellants need only establish that Friedman was at fault in the accident and damages caused by such fault in excess of Friedman's insurance policy limits. If there was any doubt after Johnson $v$. Wunderlich on the question whether it was necessary for the insured to also establish that any right of action that he may have against the tortfeasor was still subsisting, it is my view that the issue was put to rest in Chambo v. Musseau.

14 Ibid. at para. 23. On this point, Charron J.A. again relied heavily on the Chambo case, ibid., and other Ontario case law which found that a claimant's action against an SEF 44 insurer can proceed even where the action against the tortfeasor is barred by a statutory limitation period:

I see no principled reason to distinguish this case from the fact situation in Chambo v. Musseau. The fact that the appellants have compromised their right of action against the tortfeasor by entering into an agreement, as opposed to having missed a limitation period, can be of no moment. Surely missing a limitation period is the worst compromise of the action that can be made. Even if the Limits Agreement was found to have interfered with the insurer's rights of subrogation, a question which does not have to be determined on this appeal, it would not advance the insurer's position since the missing of a limitation period by a plaintiff against a tortfeasor also defeats an insurer's subrogated claim: see Royal Insurance Co. of Canada v. Aguiar, (1984) 48 O.R. (2d) 705 (C.A.). Supra note 5 .

16 McLachlin C.J.C., L'Heureux-Dubé, Gonthier and LeBel JJ. were the other Justices who signed on to lacobucci J.'s reasons for judgment.

17 See Somersall (S.C.C.), supra note 5 at paras. 21-42 for lacobucci J.'s reasoning with respect to the entitlement argument. Generally, Iacobucci J. upheld the Court of Appeal's finding that the phrase "legally entitled to recover damages" in the SEF 44 insuring agreement only requires a claimant to establish the fault of the alleged tortfeasor and the amount of the damages suffered. Justice lacobucci based his reasoning on the same line of cases relied upon by the Court of Appeal as well as on American authorities. He rejected case law to the contrary on the grounds that the wording of the endorsement in those cases was not identical to the SEF 44.

However, lacobucci J. rejected the Court of Appeal's suggestion that the need for the claimant to prove these elements means that "legally entitled to recover damages" refers only to substantive tor law principles. Instead, lacobucci J. held that the critical question is not the nature of the applicable laws, but rather whether the laws were applicable at the relevant time. According to lacobucci J., the relevant time for determining whether the claimant is "legally entitled to recover" against the tortfeasor is the time of the accident. Hence, as long as the claimant can establish the legal liability of the tortfeasor on the date of the loss, the SEF 44 is applicable. Accordingly, lacobucci $J$. concluded that, because the limits agreement did not exist at the time of the Somersalls' accident with Friedman, the limits agreement is not relevant to determining whether 


\section{A. THE MAJORITY JUDGMENT}

Justice lacobucci undertook a systematic analysis of the subrogation argument, concentrating on "four major points": ${ }^{18}$ the plain language of the contract, special principles of interpretation and general principles of law applicable to insurance contracts, court precedents, and the need for wise policy decisions regarding the interpretation of the subrogation doctrine. Beginning with the relevant principles of insurance law, lacobucci J. emphasized the doctrine of contra proferentum, which requires any ambiguity in the subrogation clause to be interpreted in favour of the insured. According to lacobucci J., this doctrine means that "only a clear and unambiguous obligation upon the insured to maintain a claim in tort and not waive it in exchange for a payment" ${ }^{19}$ would result in a ruling for the insurer. Justice lacobucci also emphasized the main objectives underlying subrogation: namely, to ensure that the insured does not receive more than full indemnity and to ensure that the burden of the loss falls on the party who caused it. With respect to these objectives, lacobucci J. stated that

if there is no danger of the insured's being over-compensated and the tortfeasor has exhausted his or her capacity to compensate the insured there is no reason to invoke subrogation. Similarly, if the insured enters into a limits agreement or otherwise abandons his or her claim against an impecunious tortfeasor the insurer has lost nothing by the inability to be subrogated. ${ }^{20}$

In this case there was no danger of over-compensating the Somersalls. Further, according to Iacobucci J., "it also appears that the Limits Agreement exhausted Friedman's capacity to compensate the respondents." ${ }^{21}$ In other words, since Friedman was unlikely to be able to personally satisfy a judgment for any amount over the limits of his insurance policy, the limits agreement did not deny the insurer a substantive or effective right of subrogation.

Still on the topic of applicable insurance law principles, Iacobucci J. noted that an insurer's right of subrogation only arises upon full indemnity being paid to the insured. Accordingly, as a matter of equity, the insurer "would not yet be entitled to assert or pursue a subrogated claim in this case" 22 because the insurer had not yet fully indemnified the insured. Justice Iacobucci also stated that insurance principles oblige the insured "to pursue any claim it has against a third party, up until such time as the insurer is entitled to and does assert control of the claim, in good faith." ${ }^{23}$ Accordingly, Iacobucci J. concluded that

so long as the [Somersalls] genuinely believed that entering into the Limits Agreement was a wise and prudent thing to have done they must be regarded as having acted in good faith. That it cannot be said

the SEF 44 is engaged.

Ibid. at para. 45 .

Ibid. at para. 48.

Ibid. at para. 50 .

Ibid. at para. 51 .

Ibid. at para. 53 .

Ibid. at para. 54. 
with absolute certainty that there was not some small amount yet to be had does not, in and of itself, support an inference that the respondents did not act honestly and in good faith. ${ }^{24}$

Justice Iacobucci then examined the subrogation provision in the SEF 44, and found that the only change which the contract made to the insurance principles outlined above was to allow the insurer to pursue its subrogation rights upon a claim being made by the insured, rather than after the insured had been fully indemnified. While the contract terms require the insured to co-operate with the insurer in pursuing a subrogated action, nothing in the contract "puts any obligation on the insured to maintain the viability of the action." ${ }^{25}$ Accordingly, with respect to the plain meaning of the SEF 44 terms, lacobucci J. held as follows:

\begin{abstract}
The entitlement of the insurer is to whatever cause of action the insured may have in respect of the accident. The insurer's entitlement to an assignment of such causes of action is not affected by the fact that such actions are not, in fact, able to be pursued successfully. In other words, the insured may be obliged to pass along whatever she has, but this obligation is still met when what she has is nothing. ${ }^{26}$
\end{abstract}

In summarizing his position on the insured's duties under the SEF 44, Iacobucci J. held that the insured is not bound to co-operate with the insurer's subrogated claim until after payment has been made by the insurer, such that any actions by the insured prior to the SEF 44 payment are immaterial. ${ }^{27}$ In any event, any contractual ambiguity as to the obligations of the insured must be construed in favour of the insured.

Turning to the topic of case precedent, lacobucci J. found that, while "the courts below have not yet fully canvassed the nature of the subrogation rights contained in the SEF 44,"28 his conclusion on the subrogation argument was consistent with existing case law. In particular, Iacobucci J. held that this conclusion follows from the cases which have allowed an insured to bring a claim against an SEF 44 insurer before obtaining judgment against the tortfeasor, even where an intervening limitation period bars any subrogated claim against the tortfeasor. ${ }^{29}$

Finally, as to public policy concerns, Iacobucci J. found that no significant harm would be imposed on the insurance industry by a finding that the effect of the limits agreement on the insurer's ability to subrogate against the tortfeasor did not vitiate the insurer's obligation to pay under the SEF 44. In lacobucci J.'s opinion, no significant harm would result since the practical value of subrogation rights is negligible in most cases because the tortfeasor is impecunious:

$\begin{array}{ll}24 & \text { Ibid. } \\ 3 & \text { Ibid. at para. } 60 . \\ 26 & \text { Ibid. } \\ 27 & \text { Ibid. at para. } 61 . \\ & \text { payment merely by } \\ & \text { prescription." } \\ 2 \times & \text { lbid. at para. } 66 . \\ 29 & \text { lbid. at para. } 68 .\end{array}$


The fact of the matter is, however, that subrogation rights against underinsured or uninsured drivers are rarely very valuable at all.... Leaving the rules of interpretation aside, there is no good policy reason for this Court to read into the contract a provision that will so gravely prejudice the insured when the insurer will likely gain little but an exemption from the very payment for which the insured has faithfully paid her monthly premiums to ensure entitlement. ${ }^{30}$

Moreover, lacobucci J. concluded that, through the setting of monthly insurance premiums, insurers can and do compensate for the risk of assuming coverage without effective recourse against a tortfeasor. Considering the "relative value of a subrogation right to an insurer and of an indemnity payment to an insured person," ${ }^{31}$ lacobucci J. concluded that his overall finding reflected sound public policy.

\section{B. The Dissenting JUdGment}

In contrast to Iacobucci J.'s decision, Binnie J.'s dissent is not expressly divided into a consideration of the entitlement and subrogation arguments, although he does, in substance, deal with both. Overall, however, the bulk of his comments are a stinging critique of lacobucci J.'s analysis of the subrogation argument. ${ }^{32}$ While acknowledging the general principle that ambiguities in insurance contracts should be construed against the insurer, Binnie J. found that the SEF 44 was unambiguous in its intent to provide the insurer with the right to subrogate against the tortfeasor for any monies paid under the endorsement, and in its intent to impose a positive obligation on the insured not to interfere with that subrogation right. ${ }^{33}$ Further, Binnie J. held that the SEF 44's subrogation provision expressly provides that the subrogation right arose upon the claim being made under the SEF 44, thereby simultaneously imposing a duty on the insured not to interfere with the insurer's subrogation rights. ${ }^{34}$

Ibid. at para. 71.

Ibid. at para. 74.

With respect to the entitlement argument, Binnie J. stated, at para. 125, that the "relevant date to establish the cause of action against the insurer is the date the action is instituted against the insurer, not ... at the earlier date when the accident occurred."

He states, at para. 91 ,

$\mathrm{l}$ interpret the language of the policy as clearly requiring the insured to refrain from acts destructive of the subrogation interest of their insurer. The language of SEF 44, in my view, is not ambiguous. Having signed away their claim against Friedman, the respondents are precluded from recovering what they thus signed away from the appellant.

Binnie J. concluded, at para. 106, that clauses 9 and 10 of the SEF 44 emphasized the importance of subrogation in the SEF 44 (reproduced at para. 105), and he noted in particular that these provisions changed the ordinary rules of subrogation so as to expand the duty of co-operation otherwise owed by the insured:

Somewhat unusually, the right of subrogation under clause 9 arises as soon as the insured makes a claim. Generally.... a right of subrogation arises only when the insurer 'makes any payment or assumes liability therefor.' The accelerated rights under clause 9 signal the importance placed on the right of subrogation in general, and in particular on putting the insurer in charge of the claim over against the tortfeasor at the earliest practicable date. The duty of cooperation, which arises on payment, presupposes that the insurer at that time has carriage of the proceedings. All of this is inconsistent, in my view, with the view taken by the Court of Appeal in this case that the respondents' voluntary destruction of the potential subrogation interest had no adverse effect on their right to claim full indemnity under their insurance policy. 
Having thus established that an insured's duty of co-operation under the SEF 44 includes an obligation not to interfere with the insurer's right of subrogation, Binnie J. went on to address Iacobucci J.'s comments regarding the likelihood of the subrogation right being a worthless right because of the probable personal impecuniosity of the tortfeasor. First, Binnie J. pointed out that, in the case at bar, there was no evidence about the financial status of the tortfeasor. ${ }^{35}$ Second, Binnie J. opined that the actual amount to be recovered in a subrogated action is not properly considered in creating subrogation law because this concern undermines the mutual relationship which the insurance contract creates between an insurer and an insured and is contradictory to one of subrogation's principle objectives, "namely to ensure that 'the loss falls on the person who is legally responsible for causing it." ${ }^{36}$ Third, Binnie J. took issue with Iacobucci J.'s finding that subrogation rights are typically of no real value to insurers:

The insurance industry does not, I think, spend millions of dollars a year pursuing subrogated claims out of an academic interest in avoidance of over-compensation of insureds or a morality crusade against wrongdoers. They do so in the expectation of recovering a significant portion of their losses from wrongdoers to reduce their overall loss experience on which the calculation of premiums is ultimately based.... A risk with recourse against the wrongdoer is different than a risk without such recourse. ${ }^{37}$

Finally, Binnie J. pointed out that neither the common law principles of subrogation nor the terms of the SEF 44 contract required the insurer to first prove the financial value of a subrogation right before being entitled to rely upon that right. ${ }^{38}$ Justice Binnie thus concluded overall that it was not

unduly burdensome to require the [Somersalls] to have exercised a level of diligence in keeping alive their rights against the tortfeasor that would be expected of them in conducting their affairs in their own interest. After all, prior to making the claim against the [insurer], they were acting on their own account, and it is not unfair that they now be held responsible for the consequences of the Limits Agreement they freely entered into. ${ }^{39}$

Ibid. at para. 116, where Binnie J. states,

There is not a tittle of evidence about the tortfeasor's 'capacity to compensate the insured' in this case. Nor is there any evidence that whatever capacity existed has been 'exhausted.' Nor is there evidence to support my colleague's statement in para. 52 that "the [insurer] 3. $\quad$ lbid. appears to have suffered no real loss as a result of its inability to be subrogated."

Ibid. at para. 117.

Ibid. at paras. 118-19, where Binnie J. states,

My colleague seems to suggest that proof of actual damage is a condition precedent to the insurer's ability to consider itself relieved from performance of a reciprocal term of the contract. However, it is trite law that the breach of contract, unlike a tort, may be complete irrespective of whether damages occur or can be proven....

There is nothing here that requires the insurer first to prove the tortfeasor has substantial personal assets before it is entitled to an assignment of 'all rights of action.' For the Court now to add the requirement that an insurer denied subrogation must prove that the denial did in fact result in 'actual or probable loss' ignores the wording of the SEF 44 and introduces unnecessary uncertainty in its day-to-day application. 


\section{COMmentary}

The major problems with Iacobucci J.'s application of the law are effectively addressed in Binnie J.'s dissent. Justice Binnie's judgment, for example, competently explains why the doctrine of contra proferentum and existing case law dealing with subrogated rights where limitation periods have expired do not necessarily lead to the conclusions reached by Iacobucci J. Accordingly, rather than revisit these details of legal analysis, my comments will focus on more fundamental considerations regarding the impact of Iacobucci J.'s analysis on the principle of subrogation in terms of both the theory and practice of insurance law.

\section{A. INSURANCE LAW THEORY}

The most obvious concern Iacobucci J.'s decision raises for subrogation as a legal principle stems from his insistence on linking the importance of this doctrine to an insurer's practical ability to recover funds from the wrongdoer through a subrogated action. As Binnie J. properly points out in dissent, there was no evidence before the Court to support Iacobucci J.'s conclusion that subrogated claims are generally of "negligible" value because the wrongdoer is impecunious. With respect, however, even if such evidence was before the Court, and again as pointed out by Binnie J., lacobucci J. should not have considered the practical utility of the subrogation right in determining whether the insured breached its contractual obligations by interfering with the insurer's ability to pursue this right. This point is fundamental and deserves to be emphasized apart from any consideration as to the wrongdoer's actual financial status in the Somersall case.

The legal right of one party to sue another is not dependent upon the very practical question of whether the lawsuit will result in a tangible recovery of damages. Whether or not one party can properly sue another is a question of law, determined only by whether a proper cause of action exists between the parties. Whether the party bringing a lawsuit will be able to effectively enforce any judgment obtained against the party being sued is a practical consideration which may impact a claimant's decision to proceed with a lawsuit, but which in no way affects the claimant's legal entitlement to sue. The principle of subrogation gives the insurance company, through its insured, a cause of action against the wrongdoer who caused the insured's loss. Just as with any other cause of action in tort or contract, the insurer's legal entitlement to pursue a judgment based on this cause of action should not be negated or influenced by the practical question of whether such a judgment could be effectively enforced. Justice Iacobucci's conclusion that any interference by the insured with the insurer's subrogation right is unimportant because a subrogated claim would not have resulted in any recovery of funds is akin to a judge finding that a lawyer who missed a limitation period for his client was not negligent because the party who would have been sued by the client if the limitation period was not missed would have likely been unable to pay any judgment obtained. In short, this analysis suggests that the existence of legal rights is somehow determined or affected by the practical, financial utility of those rights. If this was a correct approach to the law, impecunious individuals would be immune from all civil legal liability. 
Even assuming that the ability of a wrongdoer to pay a judgment is a proper consideration in applying the doctrine of subrogation, a second fundamental difficulty with Iacobucci J.'s decision arises from his conclusion that the insureds entered into the limits agreement in "good faith" and therefore did not breach their contractual obligations to the insurer. This conclusion raises a serious problem when considered in light of the now trite legal principle which states that an insurance contract is a contract of uberimmae fides or "utmost good faith." In essence, lacobucci J.'s finding suggests that a subjective test can and should be applied in determining whether a party to an insurance contract has complied with his or her obligation to act in utmost good faith. This suggestion belies all Canadian jurisprudence to date on the principle of utmost good faith and seriously undermines the significance of this principle to insurance law.

The notion that an insurance contract is an arrangement of utmost good faith stems from the recognition that the parties to an insurance contract are uniquely reliant upon the honesty and diligence of one another. The insurer, for example, relies upon the insured to be honest and diligent in conveying information to the insurer about risk factors pertinent to the insurance so that the insurer can properly evaluate and assess the requirements and cost of effective insurance coverage. ${ }^{41}$ The insurer's most practical means of obtaining such information is through the insured. The insured, on the other hand, relies upon the insurer to be diligent and honest in responding to claims in a manner that reflects the best interests and legal entitlements of the insured. ${ }^{42}$ Once a claim is made, the insured's most practical means of obtaining the required compensation is by relying upon the expertise of the insurer. In determining whether the parties to an insurance contract have fulfilled their good faith obligations, Canadian courts have consistently applied an objective standard. For example, in order to determine whether an insured failed to disclose a material risk factor to the insurer, the courts have asked whether a "reasonable insurer," knowing of the risk factor, would have charged a higher insurance premium or declined coverage. ${ }^{43}$ Similarly, in order to determine whether an insurer failed to protect the insured from an uninsured damages claim by refusing to accept a settlement offer within policy limits, the courts have asked whether the settlement refusal was "reasonable" in all of the circumstances. ${ }^{44}$

Thus, lacobucci J. appears to alter the standard test associated with the doctrine of utmost good faith by suggesting that, where an insured signs a limits agreement which prevents the insurer from pursuing a subrogated action, the appropriate test to apply is subjective: whether the insured signed the limits agreement genuinely believing that the wrongdoer was impecunious. Given that the insured's decision to sign the limits agreement pertains to the insured's good faith obligations not to prejudice the insurer's position under the insurance contract, Canadian jurisprudence indicates that Iacobucci J. should have applied an objective test in determining whether this particular good faith obligation was fulfilled. Further, apart from the fact that judicial precedent 
imposes an objective test when analysing good faith obligations, the very notion of utmost good faith seems to require the application of an objective standard. Would the interests of the insurer really be protected by asking if a reasonable insured would have disclosed given information? Would the interests of the insured be protected by asking if the insurer genuinely believed that a judgment at trial would be less than an offer made within policy limits? Clearly, applying subjective standards to the doctrine of utmost good faith makes the doctrine virtually meaningless and undermines the notion of mutual reliance which the doctrine of utmost good faith is designed to protect. This same effect on the doctrine of utmost good faith is achieved by lacobucci J.'s use of a purely subjective test in evaluating the insured's decision to take a step which, in its effect, eliminated the insurer's subrogation rights. The point of the doctrine of utmost good faith is that each party to an insurance contract is obliged, to some degree, to protect the interests of the other party. The doctrine is meaningless if the test applied is simply whether the party honestly believed it was not doing a disservice to the other party or failed to realize that its actions would impact on the other party's rights.

Finally, Iacobucci J.'s reasoning appears to be grounded in a much more fundamental criticism or questioning of subrogation than is merited by the facts of the case. By expressly characterizing subrogation in general as being of "negligible value" and concluding that the insurer's inability to exercise this right was therefore legally insignificant, lacobucci J. implicitly encroached on the basic and often-raised question of whether subrogation is a necessary or desirable doctrine of insurance law. This question stems from concerns that subrogation necessarily promotes litigation, which in turn involves court expenses and thereby imposes additional costs on the overall insurance system. The issue is whether the objectives of subrogation can be more efficiently achieved by other means which do not result in such increased costs. ${ }^{45}$ While this question of policy is undoubtedly worthy of discussion, the matter has no place - either explicitly or implicitly - in a judgment dealing with the facts raised in Somersall. The insurance system established by the legislature and at issue in Somersall expressly accepted and adopted the common law notion of subrogation, subject to limited modifications by contract or statute. Thus, as a matter of law, the role of the court in this case was to determine how the principles of subrogation impacted the rights of the parties involved, not whether subrogation principles should impact the parties or the insurance system in general. Justice lacobucci's comments regarding the utility or the value of the subrogation right pertain to the latter topic.

\section{B. Insurance Practice}

Particularly in jurisdictions where automobile insurance operates in a fault or tortbased system, automobile insurance endorsements such as the SEF 44 are very common 
and highly recommended. ${ }^{46}$ Accordingly, the practical implications arising from the Supreme Court's ruling in Somersall are widespread. The practical effect of the Somersall decision is that insurers will be less certain of their ability to rely on the courts to ensure that their contractual interests in general and subrogation interests in particular cannot be flouted or thwarted unduly by the actions of their insureds. This uncertainty is compounded by the fact that the majority judgment of the Supreme Court did not provide any guidance or rationale for determining what standard or type of evidence an insurer would have to raise to demonstrate that an insured did not act in good faith in interfering with an insurer's contractual right to subrogation or to any other contractual entitlement. From a business risk-management perspective, insurance companies will likely and reasonably attempt to account for this uncertainty by increasing insurance premiums. If insurance companies interpret the Somersall decision as reflective of a general unwillingness of the Supreme Court to strictly enforce the good faith obligations of insureds (beyond the single topic of subrogation), insurers will increase premiums regardless of whether lacobucci $\mathrm{J}$. was correct in determining that subrogation, being of negligible value, is not taken into account by insurers in establishing premium rates. If the Supreme Court's decision is viewed narrowly as simply expressing the Court's view of the insurer's subrogation right and the insured's co-operation duties under the SEF 44, an obvious solution would be for insurers to amend the terms of the SEF 44 to more precisely stipulate the parameters of these contractual elements. In any event, this case will likely have a chilling effect on the willingness of insurers to rely on the courts to protect their contractual interests. While such a chilling effect is not a factor that the Court should ordinarily have in mind in deciding cases, this consideration becomes relevant when, as I have argued with respect to this case, the Court renders a decision which steps outside of the established boundaries or understandings of basic insurance law principles.

\section{CONCLUSION}

As with most areas of law, the essential principles of insurance law are in large part dependent upon one another and must be looked at both individually and as part of the larger legal scheme in order to be fully understood. In Somersall, the majority of the Supreme Court issued a decision which, for the reasons pointed out by Binnie J., fails to account for very basic elements regarding the doctrine of subrogation. As I have attempted to point out in this commentary, the ruling of the majority of the Supreme Court also fails to consider the parameters and requirements of subrogation in the larger context of more general common law and insurance law principles. Consequently, the Supreme Court's ruling reflects a narrow view of an issue which has wide repercussions for both insurance law theory and practice. This result is particularly troublesome and frustrating because, coming from a Supreme Court of Canada decision, these repercussions will likely be felt in Canadian insurance law for years to come.

4. The importance of the SEF 44 is emphasized by case law wherein insurance agents have been held liable for failing to point out or recommend to their clients the availability of an SEF 44 endorsement or its equivalent. See, e.g. Fletcher v. Manitoba Public Insurance Co., [1990] 3 S.C.R. 191 . 